\section{Birth Control: American Universities and Equal Protection}

Received: January 22, 2018; Accepted: January 31, 2018; Published: February 07, 2018

\begin{abstract}
Cusack CM*
Department of Justice and Human Services, Nova Southeastern University, 3301 College Ave, Fort Lauderdale, USA
\end{abstract}

\section{*Corresponding author: Cusack CM}

\section{carmenmercedescusack@hotmail.com}

Department of Justice and Human Services, Nova Southeastern University, 3301 College Ave, Fort Lauderdale, USA.

Tel: (954)2627563

Citation: Cusack CM (2018) Birth Control: American Universities and Equal Protection. J Contracept Stud Vol.3 No.1:3

have children are protected. Women, who have the same rights, are not protected because they can be denied some coverage based on their choices not to procreate, bear, or have children. Religious zealots may fear that birth control disintegrates a main theme of Christianity: infanticide [3]. For example, childkilling rituals are stopped, yet absolved in the Bible. Legalization of birth control has directly correlated with waning of religion's control in the United States. They ferociously warn against the sin of abortion and have demanded that it not be covered by insurance. This is the same Constitutional error as failure to cover birth control. The government cannot choose for women. The law must be enforced evenly. If pregnant women are entitled to protection, then women choosing to prevent or end pregnancy must be entitled to the same benefits. The right to choose cannot be contingent on outcome. Once a state has an interest in a fetus (e.g., after viability) or after a child is born, then other rights may attach, such as the right to parent, which is dormant for a woman, who chooses not to have children.

Discursive evidence of sexism abounds. For example, college campuses permit men to peel off their shirts and reveal school colors at football games, but women must retain some clothing lest they be challenged by campus police and escorted from the premises [4]. Male bees in honey bee programs are segregated, while females are mistreated. Some zoos working with colleges teach students to take young cubs from mothers despite obvious heartbreak; and some fathers may be deprived of ever seeing their cubs or having intimate family relationships (e.g., coitus). These methods of segregating males from females firmly plant 
into students the belief that they deserve to be discriminated by universities seeking to fulfill traditional agendas of suppressing women's procreative freedoms and denying equality to men (e.g., failure to produce quality pills for males punished by sensation-decreasing condoms).

Commentary about birth control has become so hostile in the United States that it has spilled onto vehicles. This medium is silent, albeit powerful, because traffic collations are unavoidable. Below are some examples of the hostile and uncomfortable pontifications blustered by American motorists [5] (Figures 1 and 2).

This vehicle explicitly depicts firearms to insinuate the uterus, womb, and ovaries of a female in order to intimidate the right to choose. The message reads: "OUTLAW," an insinuation that women exercising their right to abort should be jailed. This is a

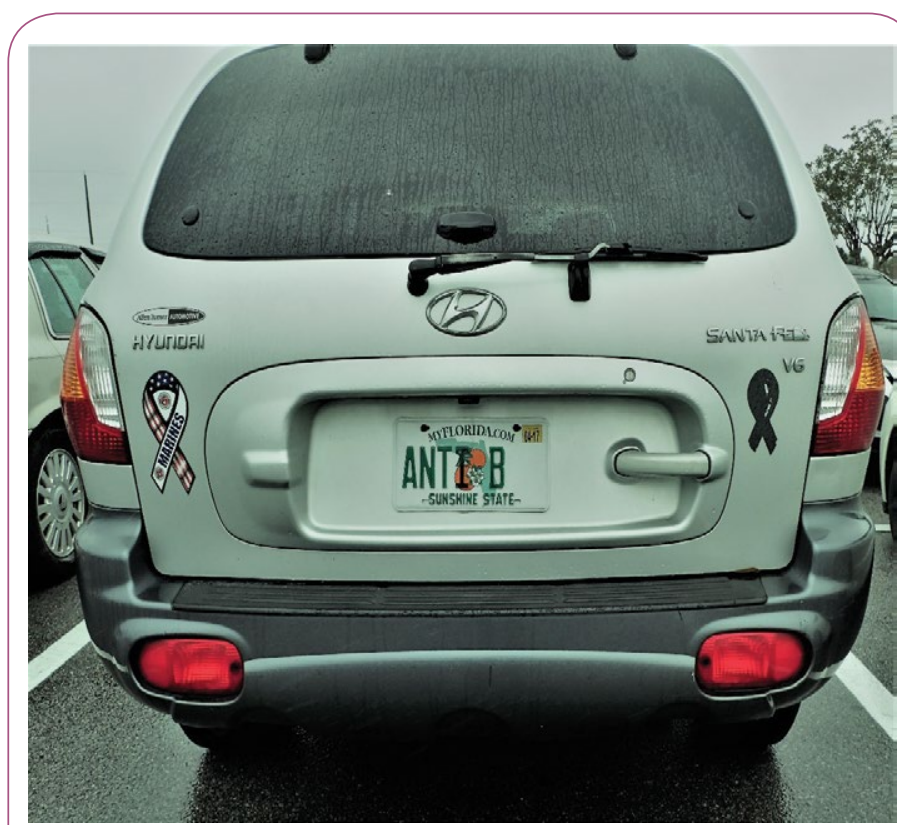

Figure 1 This vehicle professes "Anti-B," a statement against Plan B bolstered by this motorist's identification with the United States Marines.

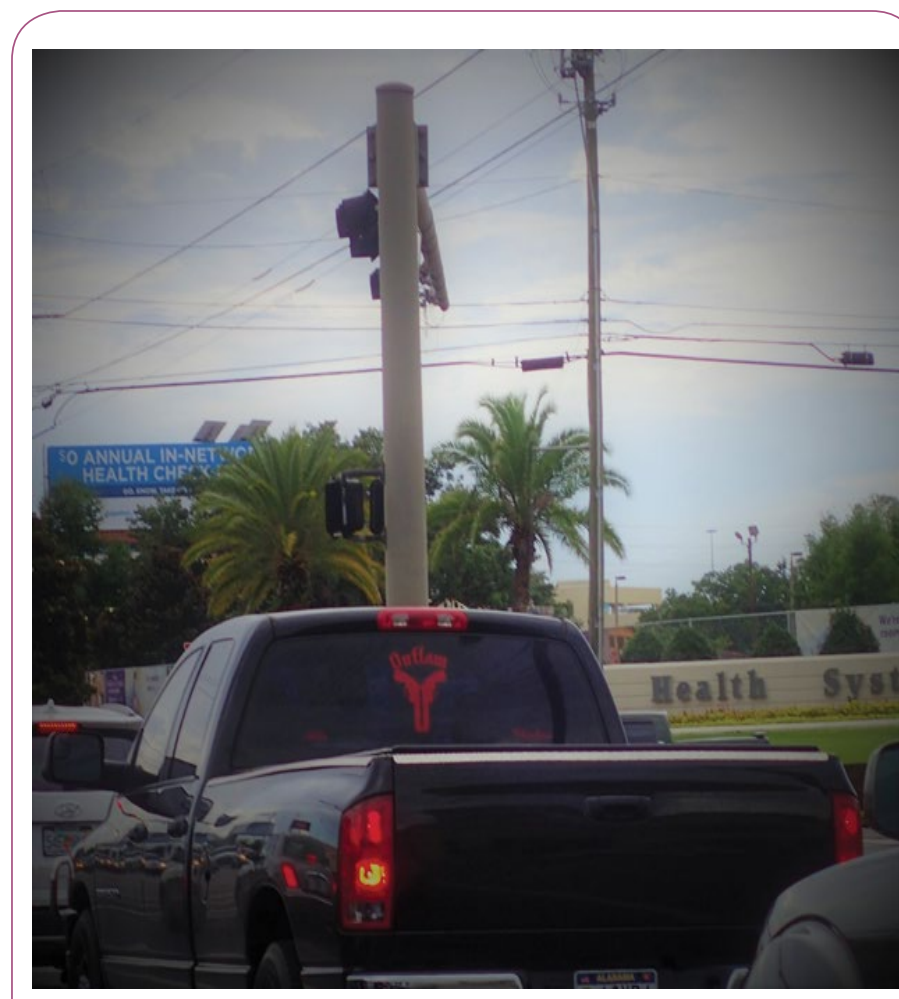

Figure 2 This vehicle explicitly depicts firearms to insinuate the uterus, womb, and ovaries of a female in order to intimidate the right to choose.

common rhetorical threat among motorists, who have insisted that the elected and ousted president, Hillary Rodham Clinton, should be incarcerated. Contributing to intelligentsia and maintaining her position of authority in the War on Women and Schools, Clinton has said that she will resume teaching at a university this fall. Her selected university, Columbia, is known for a sexual assault case resulting in the victim creating art. She dragged a full-size dormitory mattress to each class for several weeks to denounce her attacker. New Yorkers continue to stand on the forefront of gender equality, not only when Senator Clinton was in office, but before her tenure when they equalized nudity laws.

\section{References}

1 Burwell V (2014) Hobby Lobby Stores, Inc., 573 U.S.

2 Obladen M (2016) From Right to Sin: Laws on Infanticide in Antiquity, NEONATOLOGY 109: 56-61.

3 Cusack CM (2012) Boob Laws: An Analysis of Social Deviance within

Gender, Families, or the Home (Etudes 2). 33 Women's RTS. L. RPTR 197.

4 Cusack CM (2017) Anti-B. Personalized license plate beside U.S. Marines and Prisoner of War ribbons.

5 Cusack CM (2017) Pistil "Outlaw" decal with two pistols in the form of female reproductive organs. 